\title{
Indirect Determination of Nitrite by Flame Atomic Absorption Spectrometry Using a Lead(IV) Dioxide Oxidant Microcolumn
}

\author{
Meissam Noroozifar, ${ }^{*}$ Mozhgan Khorasani-Motlagh, ${ }^{\dagger}$ Aboozar Taheri, and Marjan Homayoonfard \\ Analytical Research Laboratory, Department of Chemistry, University of Sistan \& Baluchestan, \\ Zahedan, P.O.Box98165-181, Iran. E-mail: mnoroozifar@chem.usb.ac.ir \\ ${ }^{\dagger}$ Inorganic Research Laboratory, Department of Chemistry, University of Sistan \& Baluchestan, Zahedan, Iran \\ Received November 30, 2005
}

\begin{abstract}
A new, simple and fast flow injection analysis (FIA) method has been developed for the indirect determination of nitrite. The proposed indirect automatic method is based on the oxidation of nitrite to nitrate using a lead(IV) dioxide oxidant microcolumn where the flow of the sample through the microcolumn reduces the $\mathrm{PbO}_{2}$ solid phase reagent to $\mathrm{Pb}(\mathrm{II})$, which is measured by flame atomic absorption spectrometry. The absorbance of $\mathrm{Pb}$ (II) are proportional to the concentration of nitrite in the samples. The calibration curve was linear up to $30 \mathrm{mg} \mathrm{L}^{-1}$, with a detection limit of $0.11 \mathrm{mg} \mathrm{L}^{-1}$ for a $400 \mu \mathrm{L}$ injected sample volume and a sampling rate of about $80 \mathrm{~h}^{-1}$. The results exhibit no interference from the presence of large amounts of ions. The developed procedure was found to be suitable for the determination of nitrite in foodstuffs and wastewaters. A relative standard deviation better than $0.9 \%$ was obtained in a repeatability study. The reliability of the method was established by parallel determination against the standard method.
\end{abstract}

Key Words : Nitrite, Solid-phase reagent, $\mathrm{PbO}_{2}$, Flow injection analysis, Flame atomic absorption spectrometry

\section{Introduction}

The nitrogen cycle involves several important biological and abiotic processes that are related to the production of nutrients essential for the growth of microorganisms. ${ }^{1,2}$ Nitrite, nitrate and ammonium ions take part in several important environmental transformations involving nitrogen. Nitrate and ammonium are sources of nitrogen for the synthesis of proteins by microorganisms. However, large amounts of these species may be toxic and cause eutrophication. ${ }^{1,2}$ Nitrite ions are toxic even in low concentrations and may cause death by asphyxia. ${ }^{1}$ Recent evidence suggests that plasma nitrite anion represents a latent substance that can be reacts by hemoglobin in areas of hypoxia to elicit vasodilation. ${ }^{3}$ Analysis of this compound revealed a nitro substitution of the heme vinyl group, which caused little change in the ligand binding properties of the heme protein. ${ }^{4}$ This reaction appears to be largely responsible for the 'greening' of cured meats and can also be observed with hemoglobin. Nitrite has also been reported to bind to methemoglobin to form a reversible complex with a dissociation constant of between 1 and $3 \mathrm{mM}^{5,6}$ Nitrite can react with secondary or tertiary amines present in the body and water resulting in the formation of nitrosamine some of which are known to be carcinogenic. ${ }^{7-10}$ Furthermore, when present at high concentration in blood it can react with iron(III) of the hemoglobin, forming methemoglobin which has no oxygen carrying ability and this disease is called methemoglobinemia. ${ }^{11}$ Therefore, the determinations of nitrite in foodstuffs and wastewaters have attracted much attention and a simple, sensitive and specific determination of nitrite is highly desirable.

Recently, a number of different techniques for the quan- titative determination of nitrite have been reported, which include electrochemistry, ${ }^{12-14}$ chromatography, ${ }^{15-17}$ capillary electrophoresis, ${ }^{18-20}$ spectrophotometry, ${ }^{21,22}$ flow analysis-vapor phase generation-fourier transform infrared, ${ }^{23}$ electron spin resonance, ${ }^{24}$ sonoelectrochemical analysis, ${ }^{25}$ electrokinetic flow analysis system, ${ }^{26}$ gas-gap sensor ${ }^{27}$ and spectrofluorimetry. ${ }^{28-39}$ However, there are several disadvantages of using these methods such as low sample frequency, application of complicated flow injection systems, poor reproducibility and expensive.

Today, it is known that the use of solid-phase reactors incorporated into flow injection analysis manifolds may offer certain advantages over homogeneous systems such as decreasing of reagent consumption, utility for the in situ preparation of unstable reagents and simplification of the system with fewer junctions for mixing of reagents, sample and carrier streams. ${ }^{40-42}$ There are a few studies about using solid-phase reactors for determination of inorganic and organic compounds. ${ }^{40-51}$ So, it is important to find these kinds of reagents for application in every laboratory.

To the best of our knowledge, no solid-phase reactor and atomic absorption spectrometry have been reported for determination of nitrite. Our basic study has been shown that in an acidic media, nitrite can reduce $\mathrm{PbO}_{2}$ to $\mathrm{Pb}(\mathrm{II})$. The present paper describes for first time the details of the development of a lead(IV)dioxide solid-phase reactor for automatic indirect determination of nitrite with a flame atomic absorption spectrometry (FAAS) detection system.

\section{Experimental Section}

Reagents and solutions. All reagents were prepared from analytical reagent grade chemicals unless specified otherwise. 
All aqueous solutions were prepared with re-distilled water. Nitrite stock solution $1000 \mathrm{mg} / \mathrm{L}$ was prepared freshly before each measurement by dissolving $0.1500 \mathrm{~g}$ sodium nitrite (Merck) in $100 \mathrm{~mL}$ water. Working standard solutions of nitrite were prepared daily by dilution of the standard stock solutions. The solution for the carrier stream was prepared by dilution of $\mathrm{HNO}_{3}$ (Merck) with re-distilled water to a final concentration of $0.1 \mathrm{M}$. The silica gel beads (mesh 230-400, 0.04-0.063 mm; Merck) were treated for three hours at $950{ }^{\circ} \mathrm{C}$ for irreversible dehydration ${ }^{52}$ before mixing with Lead(IV) dioxide (Merck).

Our standard spectrophotometric method has been reported previously by Rincón and Martínez. ${ }^{53}$ Reagents was prepared as follow; $0.5 \mathrm{~g}$ sulphanilamide dissolved in $30 \mathrm{~mL}$ acetic glacial acid and added $120 \mathrm{~mL}$ of warm water, and filtered. Coupling reagent solution: $0.25 \mathrm{~g} \mathrm{~N}$-(1-naphthyl)ethylenediamine dihydrochloride (NED) dissolved in water. Diluted to $250 \mathrm{~mL}$ with water. Stored in a well-stoppered brown bottle and kept in a refrigerator. These reagents are used in the general procedure for standard method given as follow. Add $2.5 \mathrm{~mL}$ of sulphanilamide solution to aliquot containing nitrite in $50 \mathrm{~mL}$ standard flask and mix. After 5 minutes, add $2.5 \mathrm{~mL} \mathrm{~N}$-(1-naphthyl)-ethylenediamine dihydrochloride solution, dilute to the mark and mix. After 20 min, measure the absorbance at $545 \mathrm{~nm}$, using a reagent blank solution (containing $2.5 \mathrm{~mL}$ of sulphanilamide solution and $2.5 \mathrm{~mL}$ of $\mathrm{N}$-(1-naphthyl)-ethylenediamine dihydrochloride solution reagent and $45 \mathrm{~mL}$ water in $50 \mathrm{~mL}$ standard flask).

Instrumentation. A schematic diagram of the flow injection (FI) system is given in Figure 1. A variable flow-rate peristaltic pump, (IKA.Schlauchpumpe, Janke \& Kunkel GMBH, IKA. Labortechnik, PA.B1) was used to pump carrier-streams and the sample through the manifold at a flow rate of $3.5 \mathrm{~mL} / \mathrm{min}$. Manifold lines consisted of 0.8 $\mathrm{mm}$ i.d. polyethylene tubing. The six-way injection valve (Rheodyne, Model 7125) allowed the sample to be directly loaded into a $400 \mu \mathrm{L}$ loop, and subsequently injected into the carrier stream. The injection valve was kept in the load position for the first $10 \mathrm{~s}$ of every run to load the sample loop, after which it was switched to the inject position to place the sample plug into the carrier stream. The valve was kept in the inject position for a further $35 \mathrm{~s}$ to ensure that the entire sample was flushed out of the sample loop. This was followed by switching the valve to the load position to fill the sample loop for the next run. After being placed in the carrier stream, the sample zone was pumped through the solid-phase reactor. The products were channeled to a Philips flame atomic absorption spectrometer (Model PU 9110X) with an air-acetylene flame and $5 \mathrm{~cm}$ optical pathlength (burner). The light source was a $\mathrm{Pb}$ hollow cathode lamp. The wavelength was set to $217 \mathrm{~nm}$ with a spectral slitwidth of $0.5 \mathrm{~nm}$ and a lamp current of $7 \mathrm{~mA}$.

The solid-phase reactors. The solid-phase reactor was constructed from stainless tubing with i.d. of $0.7 \mathrm{~mm}$ and length of $120 \mathrm{~mm}$. The tubing was packed by silica gel beads embedded in solid $\mathrm{PbO}_{2}$. The reactor was prepared by mixing $0.5 \mathrm{~g}$ powdered solid Lead(IV) dioxide (Merck) and $1.5 \mathrm{~g}$ of silica gel beads. This mixture was homogenated using an IR vibration mill (Shimadzu, Japan). Each packed reactor had to be conditioned for at least $30 \mathrm{~min}$ before use. Conditioning involved pumping re-distilled water through the reactor for $15 \mathrm{~min}$ followed by pumping the carrier stream, $0.1 \mathrm{M} \mathrm{HNO}_{3}$, for another $15 \mathrm{~min}$ at flow rate of 3.5 $\mathrm{mL} / \mathrm{min}$. The lifetime of each reactor was established by comparing absorbance for the same standards from day to day. When the absorbance started to decrease systematically and drastically, the reactor had to be replaced. The total number of samples that could be processed with one column varied between 800 and 850 , depending on the nitrite concentration.

Real samples. Meat products $(10 \mathrm{~g})$ were weighed in a beaker. Deionized water $(150 \mathrm{~mL})$ was added and blended for $2 \mathrm{~min}$ in a laboratory blender. The suspension was incubated for $15 \mathrm{~min}$ in a warm water bath at $50{ }^{\circ} \mathrm{C}$. After cooling, the volume was diluted to $250 \mathrm{~mL}$ and filtered through a Whatman filter paper no. 1. An aliquot of this solution was then filtered from a $0.45-\mathrm{mm}$ cellulose acetate filter disc. The resulting solution was injected directly. The proposed method was tested with different wastewaters; the samples were filtered with Whatman filter paper no. 1 and determined by the proposed method. The original nitrite concentration of these samples was also determined before spiking.

\section{Results and Discussion}

Analysis with $\mathrm{PbO}_{2}$. It is the aim of the present work to investigate the possibility of using a solid-phase lead(IV) dioxide reactor for on-line oxidation of $\mathrm{NO}_{2}^{-}$in an FI system

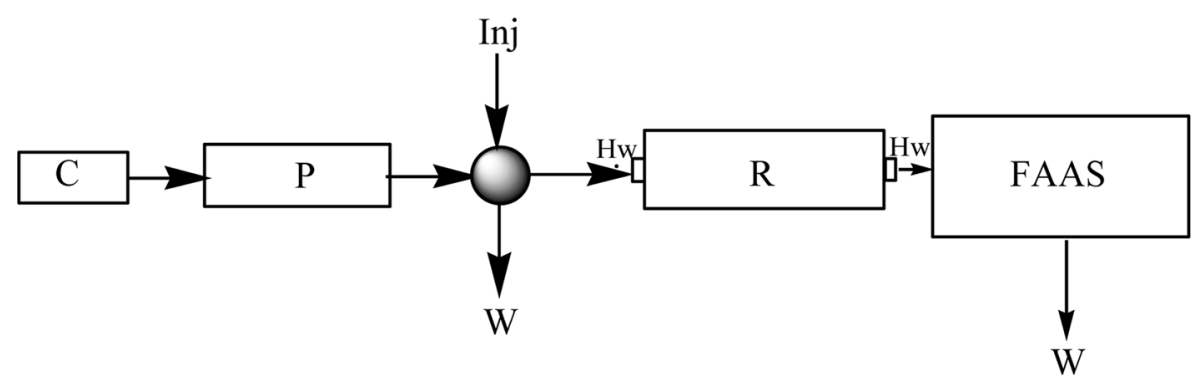

Figure 1. Schematic diagram of the single-line flow system used for the determination of Nitrite. C, Carrier; P, Pump; Inj, Injector loop valve; R, Microcolumn mini-column; Hw, Haply nut and glass wool plug; FAAS, Detector; W, Waste. 
at room temperature and without any sample concentration. In this reactor, nitrite reduces $\mathrm{PbO}_{2}$ to $\mathrm{Pb}$ (II) and nitrate is formed. The equation for this reaction is:

$$
\mathrm{PbO}_{2 \text { (Solid) }}+\mathrm{NO}_{2}{ }^{-}+2 \mathrm{H}^{+} \rightarrow \mathrm{NO}_{3}{ }^{-}+\mathrm{Pb}^{2+}+\mathrm{H}_{2} \mathrm{O}
$$

The absorbance of $\mathrm{Pb}(\mathrm{II})$ is proportional to the concentration of nitrite in the sample. Hence, we used lead(IV) dioxide solid reagent for the determination of nitrite in a flow injection system. Nitrite, when added in increasing amounts, consumes lead(IV) dioxide and increases the $\mathrm{Pb}$ absorbance. The absorbance is found to increase linearly with increasing concentration of nitrite, which forms the basis for its determination.

Optimization of variables. The performance of the proposed flow-injection system depends on the efficiency of the reaction at the interface between the solid and liquid phases of the reactors. The acid $\mathrm{HNO}_{3}$ concentration in carrier stream, the $\mathrm{PbO}_{2}$ concentration in reagent section, the loop volume and the temperature also had major effects and had to be optimized.

The contact time between the sample zone containing $\mathrm{NO}_{2}{ }^{-}$and the reactor is very important for the reaction to proceed sufficiently. Because this depends on the flow rate of the sample zone through the reactor, a study of the flow rate of the carrier stream was conducted. Flow rates between 0.5 and $6.0 \mathrm{~mL} / \mathrm{min}$ were evaluated. The optimization is shown in Figure 2. The highest analytical signal (absorbance) was found for a rate of $3.5 \mathrm{~mL} / \mathrm{min}$. At the lower flow rates down to $3.5 \mathrm{~mL} / \mathrm{min}$, the resulting absorbance is low, because of increased longitudinal diffusion. Decreasing absorbance was found for flow rates above $3.5 \mathrm{~mL} / \mathrm{min}$, because the reaction between $\mathrm{NO}_{2}{ }^{-}$with $\mathrm{PbO}_{2}$ had not gone to completion. A carrier flow rate of $3.5 \mathrm{~mL} / \mathrm{min}$ was selected in order to obtain maximum sensitivity and minimum residence times. Under these conditions, at least 80 injections per hour can be performed.

Based on the above reaction, an acidic carrier is required for the completion of the reaction between $\mathrm{NO}_{2}{ }^{-}$and $\mathrm{PbO}_{2}$. Care should be taken that the concentration of the acid in the carrier stream will give optimum performance, but without any destruction to the response reactor. The response of oxidation reactor was studied by using $\mathrm{HCl}, \mathrm{H}_{2} \mathrm{SO}_{4}, \mathrm{H}_{3} \mathrm{PO}_{4}$

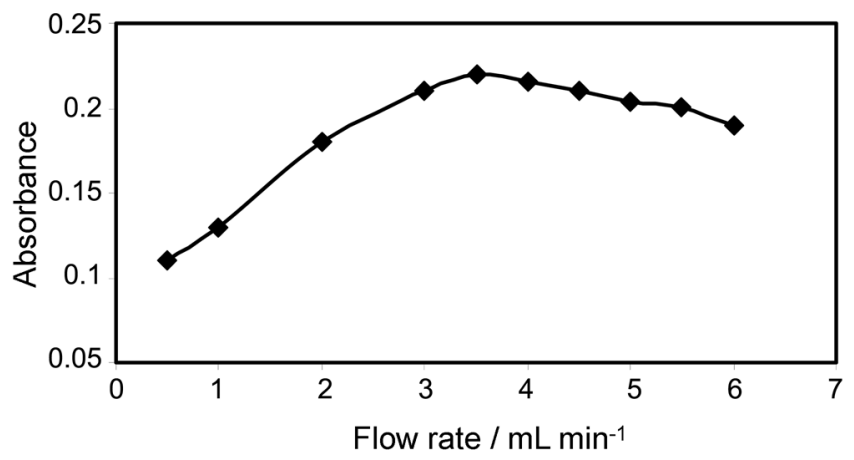

Figure 2. Influence of the carrier flow rate on the analytical signal, $\left[\mathrm{NO}_{2}{ }^{-}\right]=8.0 \mathrm{mg} / \mathrm{L}, \mathrm{T}=25^{\circ} \mathrm{C},\left[\mathrm{PbO}_{2}\right]=25 \%$, Loop volume $=400$ $\mu \mathrm{L}$, carrier stream $=0.1 \mathrm{M} \mathrm{HNO}_{3}$.

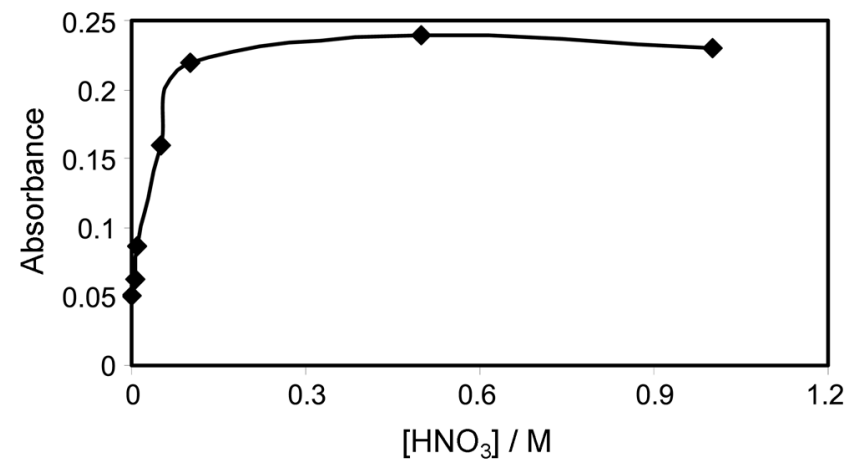

Figure 3. Influence of the carrier stream $\mathrm{HNO}_{3}$ concentration on the analytical signal, $\left[\mathrm{NO}_{2}{ }^{-}\right]=8 \mathrm{mg} / \mathrm{L}, \mathrm{T}=25^{\circ} \mathrm{C},\left[\mathrm{PbO}_{2}\right]=25 \%$, Loop volume $=400 \mu \mathrm{L}$ and flow rate $=3.5 \mathrm{ml} / \mathrm{min}$.

and $\mathrm{HNO}_{3}$ acids in the carrier stream. Nitric acid was chosen as the best acid, mainly because the greatest absorbance of the oxidation reactor was achieved with this acid. The effect of acid concentration between 0.0001 and $1.0 \mathrm{M}$ (preparation from nitric acid) was evaluated (see Figure 3 ). The analytical signals increased with an increase in acid concentration from 0.0001 to 0.1 and then were constant, so 0.1 $\mathrm{MHNO}_{3}$ was chosen as the optimum concentration.

The effect of the oxidant (lead(IV) dioxide) concentration on the performance of the method was evaluated between 5 and $35 \%$ for $\mathrm{PbO}_{2}$ : silica ratio. Figure 4 shows the results of increasing the $\mathrm{PbO}_{2}$ : silica ratio on the amount of absorbance. A $25 \% \mathrm{PbO}_{2}$ mixture was chosen to ensure longer reactor lifetime and better sensitivity.

The loop volume has a significant effect on absorbance, range of linearity and sensitivity, as one would expect. The absorbance was found to increase with the injected sample volume (see Figure 5). The height absorbance was obtained for loop volume upper of $400 \mu \mathrm{L}$. The loop volume of 400 $\mu \mathrm{L}$ was chosen as optimum.

Finally, the effect of the reactor temperature between 10 and $90{ }^{\circ} \mathrm{C}$ was evaluated. The optimization is shown in Figure 6. The analytical signals increased slowly with increasing temperature between 10 to $70{ }^{\circ} \mathrm{C}$ and then decreased

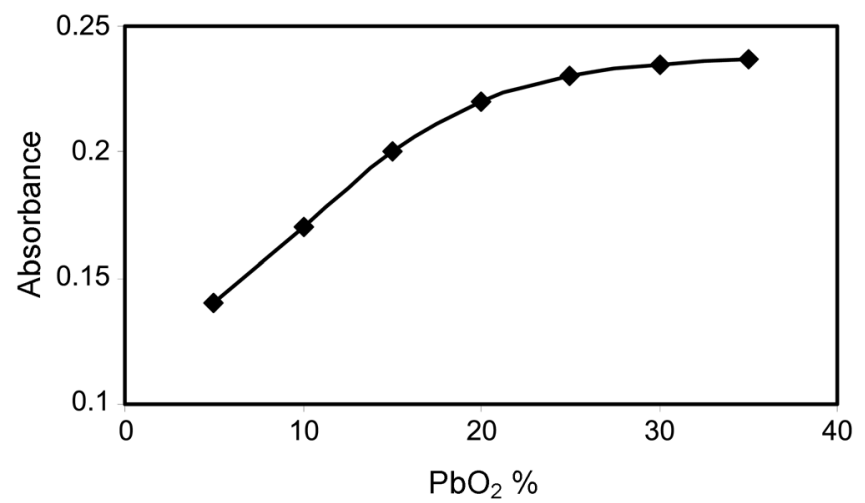

Figure 4. Influence of the solid $\mathrm{PbO}_{2}(\% \mathrm{~m} / \mathrm{m}$ suspended on silica gel beads) on analytical signal, $\left[\mathrm{NO}_{2}{ }^{-}\right]=8 \mathrm{mg} / \mathrm{L}$, carrier stream $=$ $0.1 \mathrm{M} \mathrm{HNO}_{3}, \mathrm{~T}=25^{\circ} \mathrm{C}$, Loop volume $=400 \mu \mathrm{L}$ and flow rate $=$ $3.5 \mathrm{~mL} / \mathrm{min}$. 


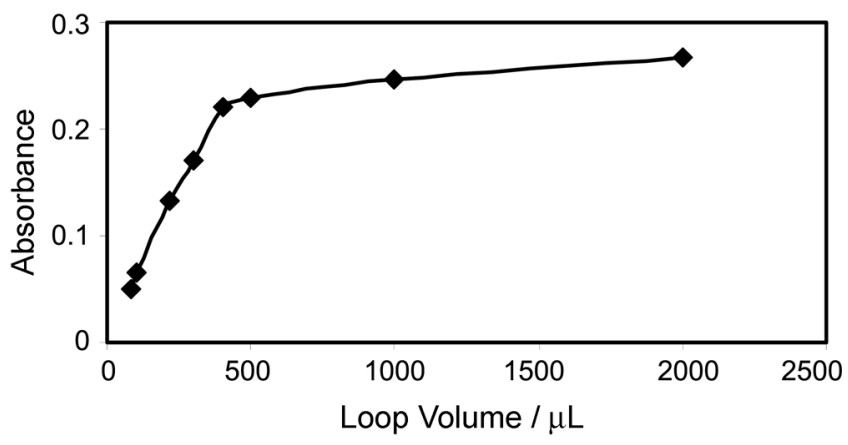

Figure 5. Influence of the injection volume on analytical signal, $\left[\mathrm{NO}_{2}{ }^{-}\right]=8 \mathrm{mg} / \mathrm{L}$, carrier stream $=0.1 \mathrm{M} \mathrm{HNO}_{3},\left[\mathrm{PbO}_{2}\right]=25 \%, \mathrm{~T}=$ $25{ }^{\circ} \mathrm{C}$ and flow rate $=3.5 \mathrm{~mL} / \mathrm{min}$.

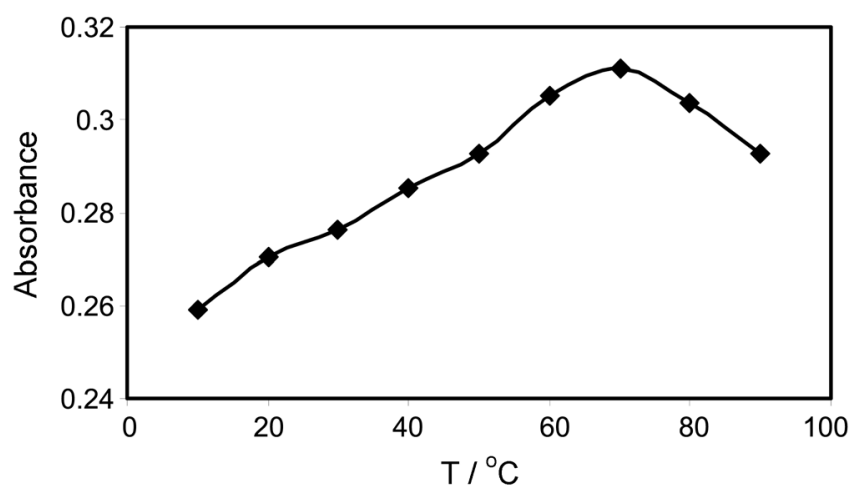

Figure 6. Influence of the reactor temperature on analytical signal, $\left[\mathrm{NO}_{2}{ }^{-}\right]=9 \mathrm{mg} / \mathrm{L}$, carrier stream $=0.1 \mathrm{M} \mathrm{HNO}_{3},\left[\mathrm{PbO}_{2}\right]=25 \%$, Loop volume $=400 \mu \mathrm{L}$ and flow rate $=3.5 \mathrm{~mL} / \mathrm{min}$.

with an increase in temperature up to $90{ }^{\circ} \mathrm{C}$. We chose $25^{\circ} \mathrm{C}$ (r.t.) as the optimum temperature for a simple system.

Sample matrix interference. The investigation of interferences was carried out for the $\mathrm{NO}_{2}^{-}-\mathrm{PbO}_{2}$ reaction, by adding the interfering element to a $\mathrm{NO}_{2}{ }^{-}$standard solution. Tolerance is defined as the maximum weight ratio of foreign compounds to $\mathrm{NO}_{2}^{-}$producing an error of $\pm 5 \%$ in the determination of $10 \mathrm{mg} / \mathrm{L} \mathrm{NO}_{2}{ }^{-}$. According to this work, no interference is observed from anions such as $\mathrm{ClO}_{4}^{-}$with weight ratio up to $1000, \mathrm{NO}_{3}{ }^{-}$with weight ratio up to 800 , $\mathrm{CO}_{3}{ }^{2-}, \mathrm{Ca}^{2+}, \mathrm{Mg}^{2+}, \mathrm{Cl}^{-}$with weight ratio up to $500, \mathrm{~S}_{2} \mathrm{O}_{8}{ }^{2-}$ with weight ratio up to $200, \mathrm{~F}^{-}, \mathrm{H}_{2} \mathrm{PO}_{4}{ }^{-}, \mathrm{S}_{2} \mathrm{O}_{5}{ }^{2-}$ with weight ratio up to $100, \mathrm{CH}_{3} \mathrm{COO}^{-}, \mathrm{Fe}^{3+}, \mathrm{B}_{4} \mathrm{O}_{7}^{2-}$ with weight ratio up to 50 and $\mathrm{IO}_{3}{ }^{-}, \mathrm{BrO}_{3}{ }^{-}, \mathrm{S}_{2} \mathrm{O}_{4}{ }^{2-}, \mathrm{S}_{2} \mathrm{O}_{5}{ }^{2-}, \mathrm{Mo}_{7} \mathrm{O}_{24}{ }^{6-}$ with weight ratio up to 1 .

Evaluation of the method. Using the experimental conditions described above, the calibration graph is linear up to $30 \mathrm{mg} / \mathrm{L}$ and is described by the equation: $A=0.003+$ $0.0308 C_{\text {nitrite }}, r=0.9992, n=10$ where $A$ is the absorbance, $C_{\text {nitrite }}$ is the nitrite concentration $(\mathrm{mg} / \mathrm{L}), r$ is the correlation coefficient and $n$ represents the number of determinations.

The detection limit $(D L)$ was calculated using the equation $D L=3 S_{b k} / m$, where $S_{\mathrm{bk}}$ is the standard deviation of blank signals for 10 determinations and $m$ is the slope of the calibration graph. The calculated $D L$ was found to be $0.11 \mathrm{mg} / \mathrm{L}$.

Precision and accuracy of proposed method. The precision of the method was determined by seven repetitive analyses of different standard solutions under the optimum conditions. The results are shown in Table 1. These results indicate that the relative standard deviation (RSD \%) and relative error ( $\mathrm{RE} \%$ ) could be better than $0.82 \%$ and \pm 2.6 , respectively. Also, the results from standard method have shown in Table 1.

The figure of merit of the proposed FI-FAAS system and many recently publications in the literature for determination of nitrite is summarized in Table 2. ${ }^{54-57}$ The figure of merit of the proposed system is better than these reported systems. However to date no such study has been directed to the use of SPR for determination of nitrite in the literatures.

Application to real samples and recovery tests. Recovery tests using the proposed method were performed using four different samples, and the test for each sample was carried out in triplicate. As shown in Table 3, the

Table 1. Precision and accuracy of the method

\begin{tabular}{cccccrr}
\hline $\begin{array}{c}{\left[\mathrm{NO}_{2}{ }^{-}\right] \text {present }} \\
(\mathrm{mg} / \mathrm{L})\end{array}$ & $\begin{array}{c}{\left[\mathrm{NO}_{2}{ }^{-}\right] \text {found with proposed }} \\
\text { method }(\mathrm{mg} / \mathrm{L})\end{array}$ & $\begin{array}{c}\mathrm{RSD}, \% \\
(\mathrm{n}=7)\end{array}$ & $\begin{array}{c}\text { Relative error, } \\
\%\end{array}$ & $\begin{array}{c}{\left[\mathrm{NO}_{2}{ }^{-}\right] \text {found with standard }} \\
\text { method }(\mathrm{mg} / \mathrm{L})\end{array}$ & $\begin{array}{c}\mathrm{RSD}, \% \\
(\mathrm{n}=7)\end{array}$ & $\begin{array}{c}\text { Relative error, } \\
\%\end{array}$ \\
\hline 2.00 & $2.03 \pm 0.03$ & 0.46 & 1.5 & $1.95 \pm 0.05$ & 1.06 & 2.5 \\
5.00 & $4.91 \pm 0.09$ & 0.82 & -1.8 & $4.93 \pm 0.07$ & 0.48 & -1.4 \\
10.00 & $10.16 \pm 0.16$ & 0.33 & 1.6 & $10.26 \pm 0.26$ & 0.73 & 2.6 \\
18.00 & $18.47 \pm 0.47$ & 0.48 & 2.6 & $17.66 \pm 0.32$ & 1.01 & -1.8 \\
\hline
\end{tabular}

Table 2. Comparison of analytical performance data with literatures

\begin{tabular}{|c|c|c|c|c|c|c|}
\hline System & Samples & $\begin{array}{l}\text { Sampling rate } \\
\text { (sample/h) }\end{array}$ & $\begin{array}{l}\text { Linear range } \\
\left(\mathrm{mg} \mathrm{L}^{-1}\right)\end{array}$ & $\begin{array}{l}\text { Detection limit } \\
\left(\mathrm{mg} \mathrm{L}^{-1}\right)\end{array}$ & $\begin{array}{c}\text { RSD } \\
(\%)\end{array}$ & Ref. \\
\hline FIA-spectrophotometry & Water & 25 & $0.36-90$ & 0.36 & 1.2 & [54] \\
\hline SIA $^{b}$-spectrophotometry (Griess reaction) & surface water & 14 & $0.16-3.29$ & 0.16 & 1.10 & {$[56]$} \\
\hline Capillary zone electrophoresis & human saliva & No data & No data & 0.7 & 1.5 & [57] \\
\hline FI-FAAS & $\begin{array}{l}\text { Foodstuffs, water } \\
\text { and wastewaters }\end{array}$ & 80 & up to 30 & 0.11 & 0.9 & This work \\
\hline
\end{tabular}

${ }^{a} \mathrm{mg} \mathrm{kg}^{-1} \cdot{ }^{b}$ Sequential injection analysis. 
Table 3. Results of recovery test

\begin{tabular}{lccccc}
\hline Sample & $\begin{array}{c}{\left[\mathrm{NO}_{2}^{-}\right] \text {added }} \\
(\mathrm{mg} / \mathrm{L})\end{array}$ & $\begin{array}{c}{\left[\mathrm{NO}_{2}{ }^{-}\right] \text {found Proposed method }} \\
(\mathrm{mg} / \mathrm{L})\end{array}$ & $\begin{array}{c}\mathrm{RSD}, \% \\
(\mathrm{n}=7)\end{array}$ & $\begin{array}{c}{\left[\mathrm{NO}_{2}{ }^{-}\right] \text {found standard method }} \\
(\mathrm{mg} / \mathrm{L})\end{array}$ & $\begin{array}{c}\text { Recovery, } \\
\%\end{array}$ \\
\hline wastewater 1 & 0.00 & $1.19 \pm 0.01$ & 0.91 & $1.15 \pm 0.02$ & - \\
& 10.00 & $11.20 \pm 0.08$ & 0.89 & $10.12 \pm 0.15$ & 100.1 \\
wastewater 2 & 0.00 & $0.99 \pm 0.02$ & 0.89 & $0.95 \pm 0.04$ & - \\
& 10.00 & $10.06 \pm 0.12$ & 0.85 & $9.96 \pm 0.22$ & 100.6 \\
Meat product 1 & 0.00 & $26.00 \pm 0.03$ & 0.41 & $25.78 \pm 0.12$ & - \\
& 10.00 & $35.86 \pm 0.14$ & 0.64 & $35.07 \pm 0.16$ & 98.6 \\
Meat product 2 & 0.00 & $55.20 \pm 0.11$ & 0.74 & $54.10 \pm 0.28$ & - \\
& 10.00 & $65.38 \pm 0.20$ & 0.79 & $65.01 \pm 0.15$ & 101.8 \\
\hline
\end{tabular}

recoveries of nitrite added to meat products and wastewaters were all between 98.6 to $101.8 \%$. The results of the recovery tests are very good. These results are compared with those obtained with standard method by the paired $t$-test. The paired $t$-test equation, applied in statistics, is

$$
t=\frac{\bar{d} \sqrt{n}}{s_{d}}
$$

where $\bar{d}$ and $s_{d}$ are the mean and standard deviation respectively of $d$ (the difference between paired values). For the pairs of values in Table 2 , the mean difference, $\bar{d}$, is 0.35 and the standard deviation of the differences, $s_{d}$, is 0.51 . The calculated $t$ was found to be 1.37 . The critical value of $t$ (tabulated $t$ ) for $n-1$ degrees of freedom (in this work 3 ) is $3.18(P=0.05)$. Since the calculated value of $t$ is less than this, the null hypothesis is not rejected: the methods do not give significantly different results for nitrite concentration. ${ }^{58}$ These results indicate that the rapid and selective proposed method could be readily implemented on a very simple and stable FIA system.

\section{Conclusions}

A new solid-phase reactor in a continuous-flow procedure is proposed for the determination of nitrite in foodstuffs and wastewater. The manifold is provided with a solid-phase reactor containing immobilized $\mathrm{PbO}_{2}$. The sample is forced through the reactor and the liberated lead ions are then monitored by a flame atomic absorption spectrometer. The procedure resulted in a selectivity which fits well with that of the real samples tested. A sample injection reproducibility of $<0.91 \%$ (RSD) was calculated. The $\mathrm{PbO}_{2}$ reagent used is cheap, stable and readily available in every laboratory. The recovery for the proposed FIA system is close to $100 \%$.

Acknowledgement. The authors gratefully thank University of Sistan \& Baluchestan (USB) for providing the financial support.

\section{References}

1. Manahan, S. E. Environmental Chemistry, $4^{\text {th }}$ ed.; Brooks/Cole: Monterey, CA, 1984.

2. Moore, J. W.; Moore, E. A. Environmental Chemistry; Academic
Press: New York, 1976.

3. Cosby, K.; Partovi, K. S.; Crawford, J. H.; Patel, R. P.; Reiter, C. D.; Martyr, S.; Yang, B. K.; Waclawiw, M. A.; Zalos, G.; Xu, X.; Huang, K. T.; Shields, H.; Kim-Shapiro, D. B.; Schechter, A.; Cannon III, R. O.; Gladwin, M. T. Nat. Med. 2003, 9, 1498.

4. Bondoc, L. L.; Timkovich, R. J. Biol. Chem. 1989, 264, 6134.

5. Rodkey, F. L. Clin. Chem. 1976, 22, 1986.

6. Fernandez, B. O.; Ford, P. C. J. Am. Chem. Soc. 2003, 125, 10510.

7. Hurst, J. K.; Lumar, S. V. Chem. Res. Toxicol. 1997, 10, 804.

8. Henery, J. G.; Heinke, G. W. Environmental Science and Engineering, $2^{\text {nd }}$ ed.; Prentice Hall: New Jersey, 1996.

9. Cox, R. D.; Frank, C. W. J. Anal. Toxicol. 1982, 6, 148.

10. Masuda, M.; Mower, H. F.; Pignatelli, B.; Celan, I.; Friesen, M. D.; Nishino, H.; Ohshima, H. Chem. Res. Toxicol. 2000, 13, 301.

11. Wang, C. J.; Huang, H. P.; Tseng, T. H.; Lin, Y. L.; Shiow, S. J. Arch. Toxicol. 1995, 70, 5.

12. Cosnier, S.; Innocent, C.; Jouanneau, Y. Anal. Chem. 1994, 66, 3198.

13. Ugo, P.; Moretto, L. M.; Ballarin, B. Electroanalysis 1995, 7, 129.

14. Davis, J.; Moorcroft, M. J.; Wilkins, S. J.; Compton, R. G.; Cardosi, M. F. Electroanalysis 2000, 12, 77.

15. Kage, S.; Kudo, K.; Ikeda, N. J. Chromatogr. B 2000, 742, 363.

16. Li, H.; Meininger, C. J.; Wu, G. J. Chromatogr. B 2000, 746, 199.

17. Helaleh, M. I. H.; Korenage, T. J. Chromatogr. B 2000, 744, 173.

18. Okemgbo, A. A.; Hill, H. H.; Siems, W. F.; Metcalf, S. G. Anal. Chem. 1999, 71, 2725.

19. Barzegar, M.; Mousar, M. F.; Nemati, A.; Lijinsky, W.; Conral, E. Microchem. J. 2000, 65, 159.

20. Öztekin, N.; Nutku, M. S.; Erim, F. B. Food Chemistry 2002, 76, 103.

21. Moshage, H.; Kok, B.; Huizenga, J. R.; Jansen, P. L. Clin. Chem. 1997, 43, 892 .

22. Yang, F.; Troncy, E.; Francoeur, M.; Vinet, B.; Vinay, P.; Czaika, G.; Blaise, G. Clin. Chem. 1997, 43, 657.

23. Gallignani, M.; Valero, M.; Ayala, C.; del Rosario Brunetto, M.; Sánchez, A.; Burguera, J. L.; Burguera, M. Talanta 2004, 64, 1290.

24. Minakata, K.; Okamoto, N.; Nozawa, H.; Watanabe, K.; Suzuki, O. Anal. Biochem. 2004, 325, 168.

25. Davis, J.; Compton, R. G. Anal. Chim. Acta 2000, 404, 241.

26. Zhao, Y.-Q.; He, Y.-Z.; Gan, W.-E.; Yang, L. Talanta 2002, 56, 619.

27. Yagodina, O. V.; Nikolskaya, E. B.; Shor, N. B. Anal. Chim. Acta 2000, 409, 143.

28. Axelrod, H. D.; Engel, N. A. Anal. Chem. 1975, 47, 922.

29. Rubio, S.; Gomes-Hens, A.; Valcarcel, M. Anal. Lett. 1984, 17, 651.

30. Ohta, T.; Arai, Y.; Takitani, S. Anal. Chem. 1986, 58, 3132.

31. Lapat, A.; Szekelyhidi, L.; Hornyak, I. Biomed. Chromatogr. B 1997, 7, 120.

32. Jie, N.; Yang, J.; Meng, F. Talanta 1993, 40, 1009.

33. Helaeh, M. I. H.; Korenaga, T. Microchem. J. 2000, 64, 241. 
34. Wang, H.; Yang, W.; Liang, S. C.; Zhang, Z. M.; Zhang, H. S. Anal. Chim. Acta 2000, 419, 169.

35. Jie, N. Q.; Yang, D. L.; Jiang, Q. B.; Zhang, Q.; Wei, L. Microchem. J. 1999, 62, 371.

36. Zhang, X.; Wang, H.; Fu, N.-N.; Zhang, H.-S. Spectrochimica Acta, Part A 2003, 59, 1667.

37. Helaleh, M. I. H.; Korenaga, T. Microchem. J. 2000, 64, 241.

38. Wang, H.; Yang, W.; Liang, S.-C.; Zhang, Z.-M.; Zhang, H.-S. Anal. Chim. Acta 2000, 419, 169.

39. Lu, C.; Qu, F.; Lin, J.-M.; Yamada, M. Anal. Chim. Acta 2002, $474,107$.

40. Andrade, F. J.; Tudino, M. B.; Troccoli, O. E. Analyst 1996, 121, 613.

41. van Staden, J. F.; Kluever, L. G. Anal. Chim. Acta 1997, 350, 15.

42. Baklemishev, M. K.; Stoyan, T. A.; Dolmanova, I. F. Analyst 1997, 122, 1161.

43. Vereda Alonso, E.; Siles Cordero, M. T.; Caballero Torres, M. P.; García de Torres, A.; Cano Panón, J. M. Analyst 1998, 123, 1561.

44. Gil Torró, I.; Garrcía Mateo, J. V.; Martínez Calatayud, J. Analyst 1997, 122, 139.

45. López Gómez, A. V.; Martínez Calatayud, J. Analyst 1998, 123, 2113.

46. Catalá Icardo, M.; Lahuerta Zamora, L.; Martínez Calatayud, J.
Analyst 1998, 123, 1685.

47. Kargosha, K.; Noroozifar, M. Anal. Chim. Acta 2000, 413, 57.

48. Noroozifar, M.; Khorasani-Motlagh, M.; Hosseini, S.-N. Anal. Chim. Acta 2005, 528, 269.

49. Noroozifar, M.; Khorasani-Motlagh, M. Asian J. Spectro. 2002, 6 , 97.

50. Noroozifar, M.; Khorasani-Motlagh, M. Talanta 2003, 61, 173.

51. Noroozifar, M.; Khorasani-Motlagh, M. Chem. Anal. (Warsaw) 2004, 49, 929.

52. Ravindranath, B. Principles and Practice of Chromatography; John Wiley \& Sons: New York, 1989; p 248.

53. Rincón, F.; Martínez, B.; Delgado, J. M. Meat Science 2003, 65, 1421.

54. Pourhossein, M.; Amini, M. K.; Talebi, M. Anal. Sci. 2005, 21, 661.

55. Andrade, R.; Viana, C. O.; Guadagnin, S. G.; Reyes, F. G. R.; Rath, S. Food Chem. 2003, 80, 597.

56. Legnerová, Z.; Solich, P.; Sklenãrová, H.; Satínský, D.; Karlĩcek, R. Water Research 2002, 36, 2777.

57. Tanaka, Y.; Naruishi, N.; Fukuya, H.; Sakata, J.; Saito, K.; Wakida, S. J. Chromatogr. A 2004, 1051, 193.

58. Miller, C.; Miller, J. N. Statistics for Analytical Chemistry; John Wiley \& Sons: New York, 1988; p 58. 